\title{
FOLLOW-UP STUDY ABOUT HYDRATION PARAM- ETERS AT MODERATE ALTITUDE: MEASUREMENTS IN HEALTHY VOLUNTEERS BASED ON BIO-ELECTRIC IMPEDANCE ANALYSIS (BIA)
}

\author{
Horst J. KOCH ${ }^{1}$, Christoph RaschKA ${ }^{2}$, JOHANNES KÄSEBIETER ${ }^{3}$ \\ ${ }^{1}$ Clinic for Psychiatry and Psychotherapy, Heinrich-Braun-Klinikum, \\ Zwickau, Germany \\ ${ }^{2}$ Institute of Sports Sciences, Faculty of Human Sciences, \\ Julius Maximilian University, Würzburg, Germany \\ ${ }^{3}$ Doctor of Veterinary Medicine, Wedemark, Germany
}

\begin{abstract}
During residence in high mountain regions, the human water hydration status changes and, from the height of $\sim 3,000 \mathrm{~m}$ above sea level, is associated with the risk of mountain sickness. The present investigation assessed this phenomenon at moderate height (1,300-2,300 $\mathrm{m}$ above sea level) after a residence time of approximately one week by means of bioelectric impedance analysis (BIA). 132 volunteers, attendees of a sports medicine congress (78 men, 54 women), agreed to enter the study. All participants underwent BIA measurements initially and after one week's time. Apart from the basic characteristics - resistance (resistor, R) and capacitor resistor (reactance, Xc) - derived characteristics such as whole body water (TBW), body cell mass (BCM) or extracellular cell mass (ECM) were of interest. Significant changes after the stay in moderate altitude were only verified with regard to hand resistance ( $\mathrm{R})$. As the resistance decreased in both men and women, tissue hydration was probably stimulated. In conclusion, the study showed that a 1-week stay at moderate altitude shows only a slight influence on the BIA parameters.
\end{abstract}

Keywords: Bio-impedance analysis (BIA); high-altitude stay; water balance; body compartments 


\section{INTRODUCTION}

Bio-impedance analysis (BIA) has gained importance in health, nutrition, and fitness research and especially in sports medicine as a non-invasive method to assess body composition [15, 16, 22]. Apart from critical statements concerning estimating the fat and fluid balance in sports medicine [12,24], the method and analogous procedures - e. g. impedance vector analysis (IVA) - are increasingly used internationally and constantly standardised $[3,18,21]$. Clinical scores have been slightly better to predict the outcome of dialysis patients compared to the BIA method, although the authors admit that impedance-vector analysis could improve the validity [3]. For practical clinical purposes, the phase angle may be a valid parameter to select risk patients with consuming illnesses, also in view of the nutritional condition in early stages $[7,20]$.

So far, there have been only a few studies that have used BIA as a method in mountain medicine or expeditions. In a pilot study, our working group found changes in water balance and body composition at moderate altitude [19]. The present study should generate new data with a larger panel of volunteers and answer the question whether the water balance of healthy subjects is altered at moderate altitude. In addition, the suitability of the method for early detection of altitude sickness at moderate heights is investigated; it has been confirmed in high mountains around 6,000 $\mathrm{m} \mathrm{[4].}$

\section{BIOPHYSICAL BASES OF PHASE-SENSITIVE BIOIMPEDANCE ANALYSIS}

The method was already described in detail in the article by Raschka et al. [19]. In the electrical circuit, we distinguish two resistors (resistance, ohmic resistance, $\mathrm{R}$ ) and reactive resistors (reactance, $\mathrm{Xc}$ ). Ohmic resistance does not show phase differences (phase angle) between current and voltage. Transferred to physiology, the pure resistance $\mathrm{R}$ corresponds predominantly to the water content of the body, whereby in our investigation a 3-compartment model was used $[5,13,17]$.

In the case of - usually sinusoidal - alternating currents, the cellular parts of the body mass (membrane; body cell mass (BCM)) act as a capacitor, so that the capacitive resistance (reactance $\mathrm{Xc}$ ) depends inversely on the applied frequency $\left(X C=\frac{1}{2 \pi f C}\right)$ and the capacitance $\mathrm{C}$ of the cells. The reactance usually amounts to $10-12 \%$ of the effective resistance $\mathrm{R}$ of tissues. The capacitive resistance Xc is a measure of the integrity of the cells acting as capacitors. Healthy cells have higher Xc values than "cachectic" ones. When alternating currents pass through 
an ideal capacitor - no real current passage - the current I rushes ahead the voltage $\mathrm{U}$ by a quarter period $\left(90^{\circ}\right.$ or $\pi / 2=\Delta \varphi ; 360^{\circ}=2 \pi=1$ period $\left.\mathrm{T}\right)$. The phase angle $\varphi$ depends on the BCM (body cell mass) and on the cell intactness (capacitance $\mathrm{C}$ ) and the frequency $\mathrm{f}$. Normally, healthy subjects reach normal values of $5-7.5^{\circ}$, and up to $9^{\circ}$ in ideal body-perfect conditions. Specifically, the phase angle can be measured using the relationship $\tan \varphi=\frac{1}{2 \pi f C R}=X c / R$ $[1,13,17]$. Values around $50 \mathrm{~Hz}$ have been found to be suited for BIA.

\section{BIOCLIMATOLOGICAL ASPECTS}

The climate in the mountains is subject to physicochemical changes compared to the plain. On the one hand, the air pressure drops, which can be calculated using the altitude formula $P(h)=p o * e^{-\Delta h / h s}$ [17] where $p_{o}$ is the normal pressure $(101.3 \mathrm{kPa}, 1013 \mathrm{hPa}), h s$ is the scale height (a scale height means factor 2.7 ; at $15^{\circ} \mathrm{C}$ approx. $8 \mathrm{~km}$ ) and $\Delta h$ corresponds to the height difference. A difference in altitude of $2 \mathrm{~km}$ means a reduction in air pressure to around 80 $\mathrm{kPa}$. The temperature decreases by around $1^{\circ} \mathrm{C}$ per $100 \mathrm{~m}$, which equates to a difference of around $20^{\circ} \mathrm{C}$ at $2000 \mathrm{~m}$. In addition, the relative humidity - colder air - goes up and the probability of precipitation (condensation) increases. Wind systems such as the valley wind in the daytime (from the valley towards the mountains) or higher radiation intensity can modulate the bioclimate [9]. Furthermore, one should not forget that the oxygen partial pressure decreases by $0.21 \times 80=16.8 \mathrm{kPa}$.

\section{METHODOLOGY}

132 subjects were included in the study. All the participants gave their informed consent. The detailed demographic and anthropometric data are summarized in Table 1. During the study, the subjects did not change their eating or smoking habits. 
Table 1. Age and body size (BS) of the volunteers.

\begin{tabular}{lll}
\hline & Age [years] & BS $[\mathrm{m}]$ \\
\hline Men & Mean $=47.3$ & Mean $=1.803$ \\
$(\mathrm{n}=78)$ & SD $=12.1$ & SD $=0.056$ \\
\hline & Median $=51$ & Median $=1.8$ \\
& Range $=44$ & Range $=0.23$ \\
\hline Women & Mean $=44.4$ & Mean $=1.698$ \\
$(\mathrm{n}=54)$ & SD $=9.71$ & SD $=0.071$ \\
\hline & Median $=48$ & Median $=1.70$ \\
& Range $=32$ & Range $=0.31$ \\
\hline
\end{tabular}

\section{Course of the study}

All the participants underwent two sequential series of measurements (period 1: 50-305 m above sea level; Period 2: after a week's stay at 1,300-2,300 m above sea level). The following measured values were determined for all the test persons within 48 hours of their arrival in St. Anton and after a week's stay in the mountains. Additional complaints (headache, dizziness) were queried after the second measurement. All the measurements were carried out by an experienced tester with a phase-sensitive multi-frequency device at $50 \mathrm{kHz}$ under standardized conditions between $6 \mathrm{pm}$ and $8 \mathrm{pm}$ in a lying position [13].

\section{Statistical evaluation}

All the data were evaluated descriptively (mean, SD, SEM, median, range) and presented in a suitable form as graphs or tables. The nonparametric Wilcoxon test or parametric $t$-test (paired samples) were used to assess bivariate comparisons. A p-value $<0.05$ was considered significant. The sample size planning was based on the first study $[25,26]$, assuming a difference $(\Delta)$ of 5-10 and an SD of 5; with a power of $80 \%$ for the comparison of paired samples, around 30-50 test persons per group was rational [6]. Commercial and licensed statistical software was used for the calculations: NCSS 2007 Statistical Analysis and Graphics, Version 07.1.21, NCSS LLC. Kaysville, Utah, USA, 2007; Statistica Version 6, 2000, Statsoft, Tulsa, OK, USA, 2000 and Systat Version 13; Systat Software Inc., Chicago, Il, USA, 2009 and Power Sample Size Calculations Software (Version 3.1. 6, 2009). 


\section{RESULTS}

The most important results are summarized in Tables 2 and 3 for the two subsequent periods. The corresponding changes between the control measurements are shown as box plots in Figures 1-4.

Table 2. Descriptive statistical characteristics prior to the stay in the mountains (Period 1)

\begin{tabular}{lcrrrrrr}
\hline Variable & Valid N & Mean & Median & Minimum & Maximum & Range & Std.Dev. \\
\hline Resistance50 & 66 & 499.59 & 491.00 & 373.00 & 710.00 & 337.00 & 71.16 \\
\hline Reactance50 & 66 & 55.26 & 56.00 & 38 & 71 & 33.00 & 7.06 \\
\hline Hand resist. & 35 & 109.03 & 107.00 & 76.00 & 143.00 & 67.00 & 16.08 \\
\hline Foot resist. & 35 & 123.83 & 122.00 & 40.00 & 189.00 & 149.00 & 23.05 \\
\hline Proof total & 66 & 486.77 & 434.00 & 58.00 & 993.00 & 935.00 & 258.90 \\
\hline Body water & 66 & 40.82 & 42.00 & 27.70 & 57.90 & 30.20 & 7.56 \\
\hline Lean mass & 66 & 55.75 & 57.35 & 37.80 & 79.00 & 41.20 & 10.33 \\
\hline ECM & 66 & 25.84 & 26.00 & 17.90 & 35.80 & 17.90 & 4.46 \\
\hline BCM & 66 & 29.92 & 30.85 & 17.10 & 43.30 & 26.20 & 6.30 \\
\hline $\begin{array}{l}\text { ECM/BCM } \\
\text { (Index) }\end{array}$ & 66 & 0.88 & 0.86 & 0.65 & 1.21 & 0.56 & 0.11 \\
\hline \%-cells & 66 & 53.44 & 53.85 & 45.20 & 60.60 & 15.40 & 3.00 \\
\hline Phase angle & 66 & 6.35 & 6.40 & 4.80 & 8.10 & 3.30 & 0.64 \\
\hline
\end{tabular}

Table 3. Descriptive statistical characteristics after a one week's stay in the mountain region (Period 2)

\begin{tabular}{lrrrrrrr}
\hline & Valid N & \multicolumn{1}{c}{ Mean } & Median & Minimum & Maximum & Range & Std.Dev. \\
\hline Resistance50 & 66 & 493.74 & 483.50 & 373.00 & 693.00 & 320.00 & 69.86 \\
\hline Reactance50 & 66 & 55.32 & 56.00 & 43.00 & 69.00 & 26.00 & 7.05 \\
\hline Hand resist. & 41 & 100.10 & 99.00 & 30.00 & 134.00 & 104.00 & 16.80 \\
\hline Foot resist. & 41 & 118.44 & 122.00 & 42.00 & 150.00 & 108.00 & 20.93 \\
\hline Proof total & 66 & 560.71 & 566.00 & 105.00 & 999.00 & 894.00 & 252.88 \\
\hline Body water & 66 & 41.18 & 42.40 & 28.20 & 59.90 & 31.70 & 7.61 \\
\hline Lean mass & 66 & 56.25 & 57.90 & 38.50 & 81.90 & 43.40 & 10.39 \\
\hline ECM & 66 & 25.84 & 26.30 & 17.90 & 36.10 & 18.20 & 4.40 \\
\hline BCM & 66 & 30.40 & 31.40 & 18.20 & 45.80 & 27.60 & 6.44 \\
\hline ECM/BCM & 66 & 0.86 & 0.85 & 0.66 & 1.15 & 0.49 & 0.11 \\
(Index) & 66 & 53.84 & 54.10 & 46.60 & 60.20 & 13.60 & 3.01 \\
\hline \%-cellsl & 66 & 6.43 & 6.45 & 5.00 & 8.00 & 3.00 & 0.66 \\
\hline Phase angle & 66 & & & &
\end{tabular}




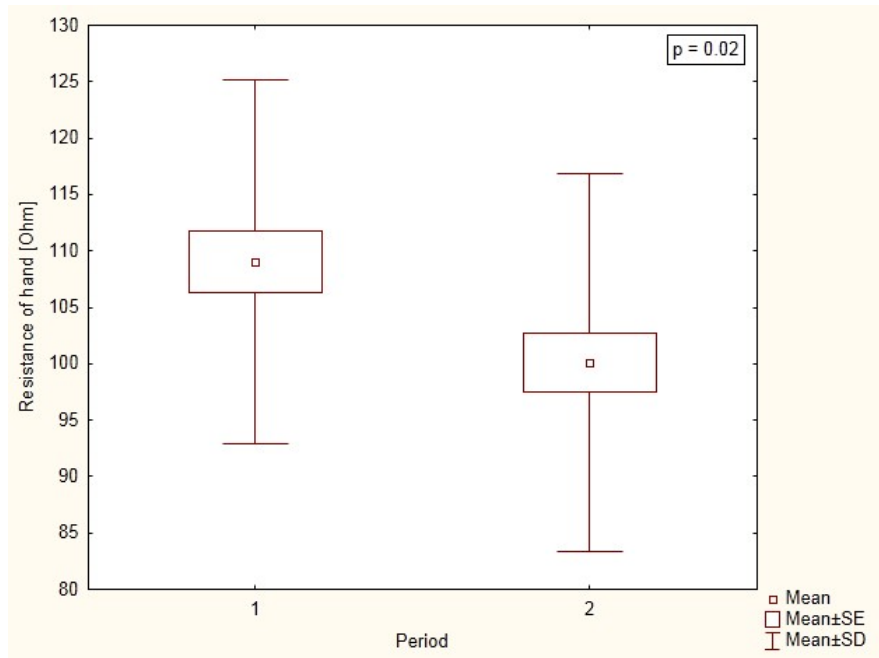

Figure 1. Hand resistance before and after the stay in the mountain region ( $p<0.05$, $t$-test, Wilcoxon-Test).

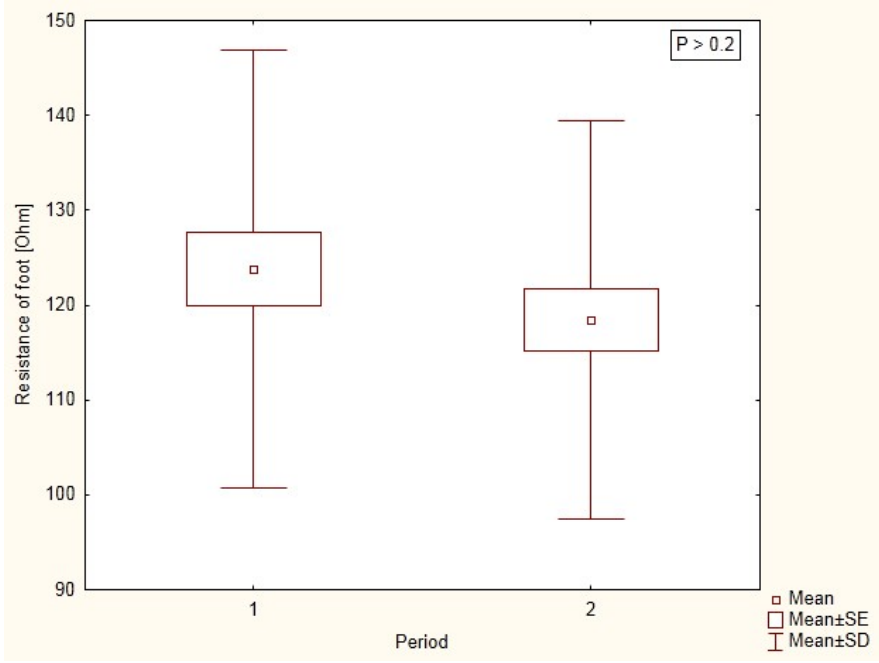

Figure 2. Foot resistance before and after the stay in the mountain region (n.s.). 


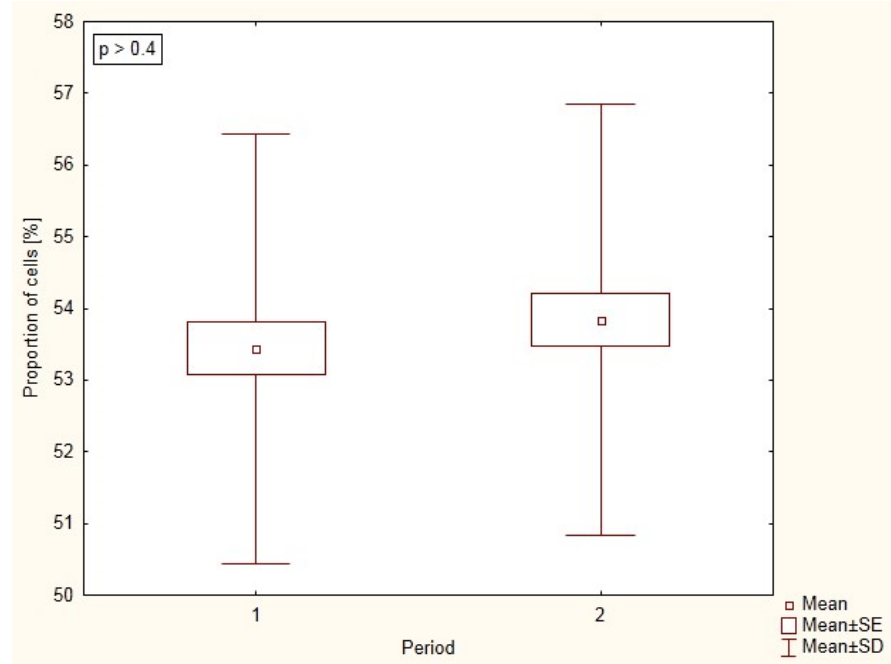

Figure 3. Proportion of cells in the tissue before and after the stay in the mountain region (n.s.).

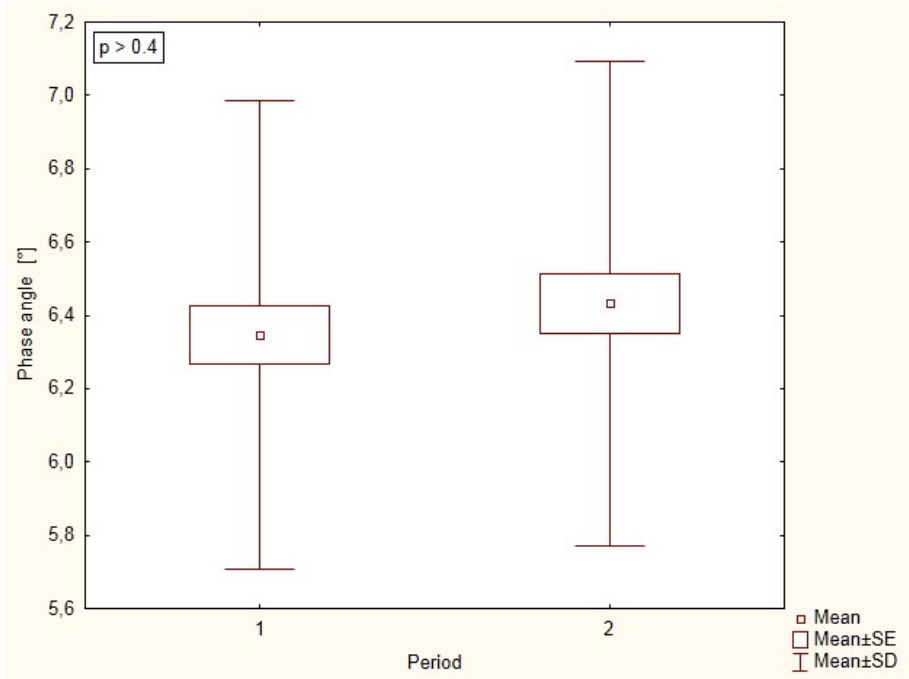

Figure 4. Phase angle before and after the stay in the mountain region (n.s).

There were tendencies for differences between periods 1 and 2; however, the values for hand resistance differed significantly between periods 1 and 2 (Wilcoxon test). The differences between men and women are known and correspond to physiological expectations (Table 4). 
Table 4. Comparison of descriptive characteristics between men and women based on data from both periods

\begin{tabular}{lrrrr}
\hline Variable & MW & m SD & MW & w SD \\
\hline Resistance50 & 445.85 & 46.42 & 557.07 & 52.85 \\
\hline Reactance50 & 53.02 & 7.10 & 58.48 & 5.65 \\
\hline Hand resist. & 102.57 & 14.05 & 106.23 & 20.03 \\
\hline Foot resist. & 199.35 & 12.05 & 122.85 & 30.13 \\
\hline Proof total & 536.94 & 244.51 & 504.66 & 276.67 \\
\hline Body water & 46.37 & 4.31 & 33.24 & 3.23 \\
\hline Lean mass & 63.39 & 5.88 & 45.40 & 4.42 \\
\hline ECM & 28.62 & 3.14 & 21.82 & 2.47 \\
\hline BCM & 34.72 & 3.50 & 23.57 & 2.64 \\
\hline ECM/BCM & 0.83 & 0.08 & 0.93 & 0.11 \\
\hline \%-cells & 54.83 & 2.46 & 53.91 & 2.88 \\
\hline Phase angle & 6.64 & 0.57 & 6.02 & 0.59 \\
\hline
\end{tabular}

Apart from hand resistance, there were no significant trends for periods. Foot resistance dropped slightly but not as significantly as hand resistance. The ECM/BCM index hardly changed, which speaks for a relatively stable cell mass. The reactance Xc-50 decreased minimally, but in percentage terms less than $\mathrm{R}$ (effective resistance), which does not indicate any substantially reduced cell integrity. The body mass did not change noticeably, the lean mass showed only a slight increase. The percentage of cells remained largely constant during the study. The phase angle as a measure of the nutritional status / cell status increased minimally on average.

The comparison of the mean values with the historical controls from 2018 showed surprisingly comparable mean differences between the first and second measurement, where: $\Delta=\mathrm{MW}-\mathrm{P} 2-\mathrm{MW}-\mathrm{P} 1$ (Table 5). This uniformity speaks for a good reproducibility of the values under comparable study conditions. No clinically relevant complaints occurred during the investigation. All the test subjects felt physically well and healthy after their stay. 
Table 5. Comparison of differences between current study data (curre.) and historical controls $(\Delta=\mathrm{P} 2-\mathrm{P} 1$ (12); contr.)

\begin{tabular}{lcc}
\hline & $\Delta$ - current & $\Delta$-contr. \\
\hline Resistance50 & -5.85 & -6.57 \\
\hline Reactance50 & 0.06 & -0.26 \\
\hline Hand resist. & -8.93 & -10.5 \\
\hline Foot resist. & -5.39 & -5.14 \\
\hline Proof total & 73.94 & 64.28 \\
\hline Body water & 0.36 & 0.33 \\
\hline Lean mass & 0.50 & 0.01 \\
\hline ECM & 0.00 & 0.05 \\
\hline BCM & 0.48 & 0.45 \\
\hline ECM/BCM & -0.02 & -0.01 \\
\hline$\%$-cells & 0.40 & 0.29 \\
\hline Phase angle & 0.08 & 0.06 \\
\hline
\end{tabular}

\section{DISCUSSION}

After a short stay in a mountain region of moderate height, the basic parameters - effective resistance, capacitive resistance or phase angle - do not change significantly in healthy test persons after one week at moderate altitude. However, especially the basic parameter - hand resistance - decreases after a stay at approximately 1,300-2,300 $\mathrm{m}$ above sea level in men and women, and to a lesser extent the phase angle. This tendency of BIA characteristics indicates a storage of body water (effective resistance decreases) during the sojourn.

Reactance and phase angle cannot be interpreted unambiguously, so that the cell integrity was not altered substantially. The quantity TBW derived from the Ohmic resistance is not markedly influenced by the stay at moderate altitude.

The results are particularly important because there are only few studies on the relevance of BIA measurements in altitude medicine. Eismann et al [4] were able to observe increasing water retention in subjects developing acute mountain sickness (AMS) at the high altitude between 4,400 and 6,100 m. In contrast, mountain climbers who did not develop AMS exhibited fluid loss. The authors consider BIA as a possible method to detect AMS at an early stage. The good agreement with the results of the previous study, which was conducted under comparable meteorological conditions, is remarkable [19]. 
Goldfarb-Rumyantzev and Alper [8] have discussed the effect of highaltitude climate, including increasing hypoxia or acclimatization, on bioimpedance and hormone balance. The reduced atmospheric pressure and oxygen partial pressure ultimately lead to increased fluid excretion at high altitude in terms of diuresis and an increase of extravascular tissue water, which in turn pathophysiologically explains the oedema (cerebral or pulmonary) of altitude sickness. As tissue water increases, ohmic resistance decreases, as in our study.

Recommendations for practice must be formulated with caution. There is a tendency for the organism to retain tissue water even at moderate altitude, which ultimately leads to AMS. From this, it can be cautiously deduced that pharmaceuticals for the treatment of headache should not enhance this effect. Classical nonsteroidal anti-inflammatory analgesics (NSAIAs or NSAIDs) appear to promote water storage, so that acetaminophen or novaminsulfone or specific therapy such as triptans would be preferable for migraine [10, 23]. Another interesting question is whether anti-inflammatory substances such as boswellic acids, antileukotrienes or bromelain can be used for symptomatic treatment $[2,11,14]$. In the future, prophylactic approaches for oedemainduced complaints in the middle and high mountains could also arise. Diuretics could exacerbate existing (vascular) hypovolemia, so that adequate fluid and mineral intake must be ensured. Especially acetazolamide, but also calcium antagonists, $B$-agonists, steroids or phosphodiesterase inhibitors have been used with varying results [8].

\section{REFERENCES}

1. Baier W., Dähnert K. (1980). Seminar Physik/Biophysik - Wechselstromkreise. Leipzig: VEB Georg Thieme, 33-37.

2. Böker D.-K., Winking M. (1997). Die Rolle der Boswellia-Säuren in der Therapie maligner Gliome. DÄB, 94, A1197-A1199.

3. Castizo-Olier J., Irurtia A., Jemni M., Carrasco-Marginet M., Fernández-García R., Rodríguez F. A. (2018). Bioelectrical impedance vector analysis (BIVA) in sport and exercise: systematic review and future perspectives. PLoS One, 13, e0197957. https://doi.org/10.1371/journal.pone.0197957

4. Eismann C., Saile P.,Schütte W., et al. (2008). Früherkennung der akuten Höhenkrankheit mit Bioimpedanzanalyse. Pneumologie, 62, 116.

https://doi.org/10.1055/s-2008-1074137 
5. Dittmar M. (2003). Reliability and variability of bioimpedance measures in normal adults: effects of age, gender, and body mass. Am J Phys Anthropol, 122, 361-370. https://doi.org/10.1002/ajpa.10301

6. Dupont W. D., Plummer W. D. (1997). PS power and sample size program available for free in the internet. Controlled Clinical Trials, 18, 274. https://doi.org/10.1016/S0197-2456(97)00074-3

7. Fiedler R., Jehle P. M., Osten B., Dorligschaw O., Girndt M. (2009). Clinical nutrition scores are superior for the prognosis of haemodialysis patients compared to lab markers and bioelectrical impedance. Nephrol Dial Transplant, 24, 3812-3817. https://doi.org/10.1093/ndt/gfp346

8. Goldfarb-Rumyantzev A. S., Alper S. I. (2014). Short-term responses of the kidney to high-altitude in mountain climbers. Nephrol Dial Transplant, 29, 497-506. https://doi.org/10.1093/ndt/gft051

9. Häckel H. (2016). Meteorologie. 8. Auflage. Stuttgart: UTB Ulmer Verlag.

10. Harvard Health Publishing. Heart-safer NSAID alternatives. https://www.health. harvard.edu/heart-health/heart-safer-nsaid-alternatives (02.11.2018).

11. Haschke M., Liechtl M. E. (2017). Metamizol: Nutzen und Risiken im Vergleich zu Paracetamol und NSAR. Schweiz Med Forum, 17, 1067-1073. https://doi.org/10.4414/smf.2017.03098

12. Herm K.-P. (2014). Methoden der Körperfettbestimmung. DZSM, 2003; 54, $153-152$.

13. Käsebieter J. Data Input GmbH - Das BIA Kompendium - IV. Ausgabe 2014. http://www.data-input.de/media/pdf-deutsch/Kompendium_III_ Ausgabe_2009.pdf. (14.09.2018).

14. Koch K. (1998), Leukotrien-Rezeptor-Antagonist: Eine neue Option für Asthma-Patienten. DÄB, 35, A-1391.

15. Kyle U.G., Bosaeus I., De Lorenzo A.D., Deurenberg P., Elia M., Gómez J. M., Heitmann B. L., Kent-Smith L., Melchior J. C., Pirlich M., Scharfetter H., Schols A. M., Pichard C. (2004a). Composition of the ESPEN Working Group. Bioelectrical impedance analysis - part I: review of principles and methods. Clin Nutr, 23, 1226-1243. https://doi.org/10.1016/j.clnu.2004.06.004

16. Kyle U.G., Bosaeus I., De Lorenzo A. D., Deurenberg P., Elia M., Manuel Gómez J., Lilienthal Heitmann B., Kent-Smith L., Melchior J. C., Pirlich M, Scharfetter H., Schols A., Pichard C. ESPEN. (2004b). Bioelectrical impedance analysis - part II: utilization in clinical practice. Clin Nutr, 23, 1430-1453. https://doi.org/10.1016/j.clnu.2004.09.012

17. Meschede D. (2010). Gerthsen Physik - Wechselströme. 24. Auflage. Heidelberg: Springer, 410-440.

18. Piccoli A., Piazza P., Noventa D., Pillon L., Zaccaria M. (1996). A new method for monitoring hydration at high altitude by bioimpedance analysis. Med Sci Sports Exerc, 28, 1517-1522.

https://doi.org/10.1097/00005768-199612000-00012 
19. Raschka C., Koch H. J., Käsebieter J. (2020). Change of hydration parameters in moderate altitude: measurements in healthy volunteers by means of bioelectric impedance analysis. Papers on Anthropology, 29(1), 40-49. https://doi.org/10.12697/poa.2020.29.1.03

20. Stobäus N., Norman K., Pirlich M. (2010). Phasenwinkel und bioelektrische Impedanzvektoranalyse - Klinische Anwendbarkeit der Impedanzparameter. Aktuelle Ernährungsmed, 35, 124-130. https://doi.org/10.1055/s-0030-1248434

21. Strapazzon G., Pun M., Cappello T. D., Procter E., Lochner P., Brugger H., Piccoli A. (2017). Total-body water dynamics estimated with bioelectrical impedance vector analysis and B-type natriuretic peptide after exposure to hypobaric hypoxia: a field study. High Alt Med Biol, 18, 384-391. https://doi.org/10.1089/ham.2017.0056

22. Tomczak J. (2003). Körperanalysen: Die bioelektrische Impedanzanalyse BIA. F.I.T. Wissenschaftsmagazin der Deutschen Sporthochschule Köln. Band 1. Lampertheim: ALPHA Informationsgesellschaft mbH, 34-40.

23. Trayes K. P., Studdiford J. S., Pickle S., Tully A. S. (2013). Edema: diagnosis and management. Am Fam Physician, 88, 102-110. Corpus ID: 16279435. https://www.aafp.org/afp/2013/0715/p102.html

24. Treff G., Steinacker J. M. Monitoring des Flüssigkeitshaushalts im Sport. DZSM, 65, 342-346. https://doi.org/10.5960/dzsm.2014.155

25. Werner J. (1984). Medizinische Statistik. Eine praktische Anleitung für Studierende, Doktoranden, Ärzte und Biologen. München: Urban \& Schwarzenberg;

26. Zar J. H. (1984). Biostatististical Analysis. $2^{\text {nd }}$ edition. Englewood Cliffs: Prentice Hall.

\section{Address for correspondence:}

Horst J. Koch

Heinrich-Braun-Klinikum, Klinik für Psychiatrie und Psychotherapie

Karl-Keilstraße 35, 08060 Zwickau

E-mail: horst.koch@hbk-zwickau.de 